\title{
PENERAPAN DATA MINING TERHADAP DATA COVID-19 MENGGUNAKAN ALGORITMA KLASIFIKASI
}

\author{
Rizka Dahlia ${ }^{1}$, Nanik Wuryani ${ }^{2}$, Sri Hadianti ${ }^{3}$, Windu Gata ${ }^{4}$, Arina Selawati ${ }^{5}$ \\ ${ }^{1234}$ Fakultas Ilmu Komputer, Sekolah Tinggi Ilmu Komputer Nusa Mandiri Jakarta \\ 5, Jl. Kramat Raya No. 18 RT. 05 RW 7, Kwitang, Kec. Senen \\ Kota Jakarta Pusat DKI Jakarta 10450 \\ ${ }^{5}$ Fakultas Teknik dan Informatika, Universitas Bina Sarana Informatika \\ 2, Jl. Kramat Raya No.98, RT.2/RW.9, Kwitang, Kec. Senen \\ Kota Jakarta Pusat, DKI Jakarta 10450

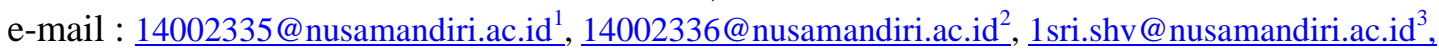 \\ windu@ nusamandiri.ac.id ${ }^{4}$, arina.asq@bsi.ac.id
}

\begin{abstract}
Coronavirus 2019 or more commonly referred to as COVID-19 is a type of virus that attacks the respiratory system. Until now the number of spread and the number of deaths caused by this virus continues to increase. As of April 21, 2020, based on data from the WHO, the total number of cases infected with this virus reached 2,397,217 with 162 deaths from all over the world. For South Korea itself, as of March 21, 2020, the total number of infected cases was 10,683 with a total of 237 deaths. In this study, researchers conducted data processing on the spread of COVID-19 in South Korea with Rapidminer using a classification algorithm, namely Nä̈ve Bayes, C4.5, and K-Nearest Neighbor by performing the stages of selection, preprocessing, transfotmating, data mining and interpretation or evaluating the quality of the best accuracy of $80.79 \%$ with AUC of 0.881 achieved by the Naïve Bayes algorithm. The distribution of the data found that the influential attribute of the isolated class factor from the patient contained in the sex attribute where more women experienced isolation.
\end{abstract}

Keywords-COVID-19, data mining, classification, C4.5, Nä̈ve Bayes, K-NN

\begin{abstract}
ABSTRAK
Coronavirus 2019 atau yang lebih sering disebut dengan COVID-19 merupakan salah satu virus jenis yang menyerang sistem pernapasan. Hingga saat ini angka penyebaran dan angka kematian yang diakibatkan virus ini terus bertambah. Per tanggal 21 April 2020, berdasarkan data dari WHO total kasus yang terinfeksi virus ini mencapai 2.397.217 dengan kasus kematian mencapai 162 kasus dari seluruh dunia. Untuk Korea Selatan sendiri, per tanggal 21 Maret 2020 total kasus yang terinfeksi mencapai 10.683 dengan total kematian sebanyak 237. Pada penelitian kali ini peneliti melakukan pengolahan data penyebaran COVID-19 di Korea Selatan dengan Rapidminer menggunakan algoritma klasifikasi yaitu Nä̈ve Bayes, C4.5, dan K-Nearest Neighbor dengan melakukan tahapan selection, preprocessing, transfotmating, data mining dan interpretation atau evaluation menghasilkan akurasi terbaik 80,79\% dengan AUC 0.881 yang diraih oleh algoritma Nä̈ve Bayes. Distribusi data yang didapatkan bahwa atribut yang berpengaruh dari faktor class isolated dari pasien terdapat pada atribut sex dimana female lebih banyak yang mengalami isolated.
\end{abstract}

Kata Kunci- COVID-19, data mining, klasifikasi, C4.5, Nä̈ve Bayes, K-NN 


\section{Pendahuluan}

Penyakit Coronavirus 2019 atau lebih dikenal dengan istilah COVID-19 merupakan suatu wabah yang awalnya terdeteksi di Kota Wuhan, Cina pada Desember 2019. Sebelum disebut sebagai COVID-19, WHO atau World Health Organization memberikan nama sementara virus baru ini sebagai Coronavirus Novel 2019 (2019-nCoV). Dan pada 21 April 2020 WHO secara resmi menyebut virus 2019-nCoV menjadi COVID-19 [1][2].

COVID-19 bermula dari betacoronavirus (SARS-CoV-2) yang menyerang bagian saluran pernapasan bagian bawah yang berubah menjadi pneumonia di tubuh manusia. Virus COVID-19 merupakan coronavirus jenis baru. COVID-19 dianggap sebagai kerabat dari Severe Acute Respiratory Syndrome (SARS) dan Middle East Respiratory Syndrome Coronavirus (MERS) [1].

Berdasarkan data yang didapat dari WHO, terdapat 179 negara yang sudah terpapar virus COVID-19. Hal menandakan bahwa virus ini memiliki tingkat paparan yang sangat tinggi dan cepat. Cara penyebarannya juga sangat sederhana. Penyebarannya dapat berupa bersin, batuk, atau berinteraksi dengan orang yang sudah terinfeksi. Dan virus ini lebih rentan terhadap orang tua dan mereka yang memang sudah memiliki riwayat penyakit serius.

Per tanggal 21 April 2020, berdasarkan data dari WHO total kasus yang terinfeksi virus ini mencapai 2.397.217 dengan kasus kematian mencapai 162 kasus dari seluruh dunia. Untuk Korea Selatan sendiri, per tanggal 21 Maret 2020 total kasus yang terinfeksi mencapai 10.683 dengan total kematian sebanyak 237. Data ini masih melakukan pembaruan hingga saat ini dan jumlah yang terinfeksi, sembuh serta meninggal akan bertambah. Ada beberapa faktor yang mempengaruhi cepatnya penyebaran virus ini yaitu umur tua, banyaknya orang bepergian ke negara yang sudah terinfeksi, melakukan kontak dengan orang yang terinfeksi, dan sebagainya [3]. Faktorfaktor tersebut dapat menjadi data dan dapat diolah dengan data mining.

Penelitian terdahulu yang menggunakan dataset Data Science for COVID-19 (DS4C) yang diambil dari kaggle yang juga digunakan pada penelitian ini pernah dilakukan oleh AlNajjar dan Al-Rousan membahas mengenai prediksi kesembuhan dan kematian pasien Covid-19 di Korea Selatan dengan algoritma yang digunakan yaitu Artificial Neural Network (ANN) dengan hasil yang didapatkan pada 
penelitian ini adalah usulan untuk memperhatikan penyebab infeksi untuk peningkatan kesembuhan pasien Covid-19 dan pengendalian regional atau daerah untuk meminimalisir kematian[4].

Penelitian dengan dataset yang sama dilakukan juga oleh Muhammad dkk. yang membahas tentang penggunaan beberapa model untuk mendapatkan akurasi tertinggi. Model yang digunakan antara lain Decision Tree, Support Vector Machine, Naïve Bayes, Logistic Regression, Random Forest, dan $K$ Newarest Neighbor. Dengan akurasi paling tinggi yang didapatkan dari beberapa model yang digunakan adalah Decision Tree memiliki akurasi yang tertinggi dengan akurasi 99.85\% [5]. Kekurangan dari penelitian ini adalah terpaku terhadap akurasi tanpa melihat matriks yang mempengaruhi baik atau buruknya sebuah model yang dibuat.

Melihat dari penelitian sebelumnya, penelitian yang akan dilakukan kali ini adalah melakukan klasifikasi dengan atribut yang digunakan yaitu sex, age, city, infaction case serta state dengan menggunakan model klasifikasi Nä̈ve Bayes, C4.5, dan K-Nearest Neighbor dengan tujuan menghasilkan klasifikasi pasien Covid-19 di Korea Selatan dengan menguji atribut yang berhubungan dengan penentuan status pasien Covid-19.

\section{Nä̈ve Bayes}

Nä̈ve Bayes merupakan salah satu algoritma data mining yang terdapat pada klasifikasi yang di ambil dari nama seorang ahli matematika yang bernama Thomas Bayes dan merupakan seorang menteri Prebysterian Inggris. Algoritma Nä̈ve Bayes menggunakan teknik percabangan matematika dengan mencari peluang terbesar dari kemungkinan dalam klasifikasi berdasarkan frekuensi tiap klasifikasi terhadap data training yang sering di sebut dengan teori probabilistik [6]. Adapun rumus perhitungan dari Nä̈ve Bayes adalah sebagai berikut [7]:

$$
P(X \mid Y)=\frac{P(Y \mid X) x P(X)}{P(Y)}
$$

$$
\begin{aligned}
& \multicolumn{2}{|c|}{\text { Keterangan : }} \\
& \mathrm{Y}= \text { data dengan kelas yang belum } \\
& \text { diketahui } \\
& \mathrm{X}= \text { hipotesis data } \mathrm{Y} \text { merupakan } \\
& \text { suatu kelas spesifik } \\
& \mathrm{P}(\mathrm{X} \mid= \text { probabilitas hipotesis } \mathrm{X} \\
&\mathrm{Y}) \text { berdasarkan kondisi } \mathrm{Y} \\
& \mathrm{P}(\mathrm{X})= \text { Probabilitas hipotesis } \mathrm{X} \\
& \mathrm{P}(\mathrm{Y} \mid= \text { Probabilitas } \mathrm{Y} \text { berdasarkan } \\
&\mathrm{X}) \text { kondisi pada hipotesis } \mathrm{X} \\
& \mathrm{P}(\mathrm{Y})= \text { Probabilitas } \mathrm{Y}
\end{aligned}
$$

\section{2. $\mathrm{C} 4.5$}

C4.5 merupakan salah satu algoritma pada metode klasifikasi dengan menghasilkan sebuah pohon keputusan. Pohon keputusan berisikan aturan yang direpresentasikan dengan bahasa yang mudah dimengerti. Dalam membuat 
sebuah pohon keputusan dibutuhkan atribut yang dipilih sebagai akar kemudian akan membentuk cabang setiap nilai. Proses itu akan diulang terus menerus hingga setiap cabang memiliki kelas yang sama[8]. Proses tersebut memiliki perhitungan yaitu sebagai berikut:

$\operatorname{Gain}(S, A)=\operatorname{Entropy}(s) \sum n * \operatorname{Entropy}(s)(2)$

Keterangan:

$\mathrm{S}=$ Himpunan Kasus

$\mathrm{A}=$ atribut

$\mathrm{n}=$ jumlah partisi dalam atribut

$|\mathrm{Si}|=$ jumlah kasus pada partisi ke-i

$|\mathrm{S}|=$ jumlah kasus dalam $\mathrm{S}$

\section{3. $\mathrm{k}-\mathrm{NN}$}

k-NN atau K-Nearest Neighbor merupakan salah satu algoritma yang di pakai dalam melakukan klasifikasi . Algoritma k-NN melakukan klasifikasi dengan cara mencari class terdekat dengan jumlah data berupa $k$ dengan class yang lain. Class terdekat dengan jumlah $k$ terbesar dipilih sebagai class untuk diprediksi dengan class yang baru [9]. Untuk mencari dekat atau jauhnya sebuah class dicari dengan persamaan sebagai berikut.

$d=\sqrt{\left(a_{1}-b_{1}\right)^{2}}+\left(a_{2}-b_{2}\right)^{2}+\cdots+$

$\left(a_{n}-b_{n}\right)^{2}$

\section{Metode Penelitian}

Metode atau tahapan penelitian sangat diperlukan ketika melakukan penelitian. Tahap penelitian dilakukan secara sistematis guna membantu penelitian agar terarah dalam melakukan penelitian. Adapun tahapan penelitian yang dilakukan pada penelitian ini sebagai berikut:

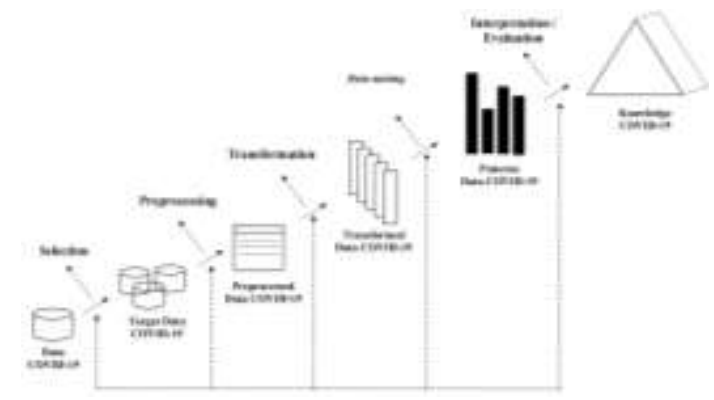

\section{Gambar 1. Tahapan Penelitian Data mining COVID-19 Algoritma Klasifikasi}

\section{a. Selection}

Sebelum melakukan proses selection lakukan terlebih dahulu pengumpulan data. Pengumpulan data dilakukan dengan mencari dataset pada repository atau jika memiliki data sendiri yang terdapat pada perusahaan jika memang dibutuhkan dalam penelitian. Kemudian pilih data yang sesuai dengan pembahasan yang ingin dibahas.

\section{b. Preprocessing}

Tahap preprocessing merupakan tahap di mana data yang sudah diseleksi kemudian dihilangkan berbagai macam data yang tidak memiliki isi atau 
kandungan. Proses ini dilakukan agar mendapatkan kualitas data yang baik.

\section{c. Transformation}

Pada tahap ini data yang telah memalui tahap preprocessing akan dilanjutkan pemilihan atribut yang tepat untuk melakukan penelitian. Atribut ini dipilih untuk mempermudah dalam melakukan proses data mining.

\section{d. Data mining}

Proses data mining merupakan proses dimana algoritma yang sudah ditentukan untuk diterapkan pada RapidMiner dengan menggunakan data-data yang sudah diolah pada proses sebelumnya serta menerapkan model yang diinginkan. Pada Proses data mining menggunakan RapidMiner akan menghasilkan sebuah keputusan atau pola berdasarkan algoritma yang ingin digunakan.

\section{e. Interpretation / Evaluation}

Pola atau keputusan yang didapat pada proses data mining disajikan dalam bentuk yang mudah dimengerti. Hal ini dilakukan untuk mempermudah seseorang dalam membaca dan melakukan koreksi hasil yang telah didapat.

\section{Hasil dan Pembahasan}

Dalam penelitian yang menggunakan Data COVID-19 didapatkan di repository kaggle.com dengan nama Science for COVID-19 (DS4C). Terdapat beberapa data yang disediakan. Namun dataset yang diambil untuk melakukan penelitian ini terfokus kepada dataset patien info. Dataset ini berisikan informasi mengenai pasien yang terpapar COVID-19 di Korea Selatan. Berikut adalah bentuk data dari dataset patien info.

Tabel 1. Contoh Data Patien info

\begin{tabular}{|c|c|c|c|c|c|c|c|c|c|c|c|c|c|c|c|c|c|}
\hline $\begin{array}{c}\text { patien } \\
\text { t_id }\end{array}$ & $\begin{array}{l}\text { global } \\
\text { _num }\end{array}$ & sex & $\begin{array}{c}\text { birth } \\
\text { _yea } \\
\mathbf{r}\end{array}$ & age & $\begin{array}{c}\text { cou } \\
\text { ntr } \\
\mathbf{y}\end{array}$ & $\begin{array}{l}\text { prov } \\
\text { ince }\end{array}$ & city & $\begin{array}{l}\text { dise } \\
\text { ase }\end{array}$ & $\begin{array}{l}\text { infection_- } \\
\text { case }\end{array}$ & $\begin{array}{l}\text { infectio } \\
\text { n_order }\end{array}$ & $\begin{array}{l}\text { infecte } \\
\text { d_by }\end{array}$ & $\begin{array}{l}\text { contact_ } \\
\text { number }\end{array}$ & $\begin{array}{l}\text { symptom_- } \\
\text { onset_date }\end{array}$ & $\begin{array}{l}\text { confirm } \\
\text { ed_date }\end{array}$ & $\begin{array}{l}\text { release } \\
\text { d_date }\end{array}$ & $\begin{array}{c}\text { dece } \\
\text { ased } \\
\text {-dat } \\
\text { e }\end{array}$ & state \\
\hline $\begin{array}{l}10000 \\
00001\end{array}$ & 2 & $\begin{array}{c}\mathrm{mal} \\
\mathrm{e}\end{array}$ & 1964 & $50 \mathrm{~s}$ & $\begin{array}{c}\text { Kor } \\
\text { ea }\end{array}$ & $\begin{array}{c}\text { Seou } \\
1\end{array}$ & $\begin{array}{c}\text { Gangse } \\
\text { o-gu }\end{array}$ & & $\begin{array}{l}\text { overseas } \\
\text { inflow }\end{array}$ & 1 & & 75 & $1 / 22 / 2020$ & $\begin{array}{c}1 / 23 / 202 \\
0\end{array}$ & $\begin{array}{c}2 / 5 / 202 \\
0\end{array}$ & & released \\
\hline $\begin{array}{l}10000 \\
00002\end{array}$ & 5 & $\begin{array}{c}\mathrm{mal} \\
\mathrm{e}\end{array}$ & 1987 & $30 \mathrm{~s}$ & $\begin{array}{c}\text { Kor } \\
\text { ea }\end{array}$ & $\begin{array}{c}\text { Seou } \\
1\end{array}$ & $\begin{array}{c}\text { Jungnan } \\
\text { g-gu }\end{array}$ & & $\begin{array}{c}\text { overseas } \\
\text { inflow }\end{array}$ & 1 & & 31 & & $\begin{array}{c}1 / 30 / 202 \\
0\end{array}$ & $\begin{array}{c}3 / 2 / 202 \\
0\end{array}$ & & released \\
\hline $\begin{array}{l}10000 \\
00003\end{array}$ & 6 & $\underset{\mathrm{e}}{\mathrm{mal}}$ & 1964 & $50 \mathrm{~s}$ & $\begin{array}{c}\text { Kor } \\
\text { ea }\end{array}$ & $\begin{array}{c}\text { Seou } \\
1\end{array}$ & $\begin{array}{c}\text { Jongno- } \\
\text { gu }\end{array}$ & & $\begin{array}{l}\text { contact } \\
\text { with } \\
\text { patient }\end{array}$ & 2 & $\begin{array}{l}20020 \\
00001\end{array}$ & 17 & & $\begin{array}{c}1 / 30 / 202 \\
0\end{array}$ & $\begin{array}{c}2 / 19 / 20 \\
20\end{array}$ & & released \\
\hline $\begin{array}{l}10000 \\
00004\end{array}$ & 7 & $\underset{\mathrm{e}}{\mathrm{mal}}$ & 1991 & $20 \mathrm{~s}$ & $\begin{array}{c}\text { Kor } \\
\text { ea }\end{array}$ & $\begin{array}{c}\text { Seou } \\
1\end{array}$ & $\begin{array}{c}\text { Mapo- } \\
\text { gu }\end{array}$ & & $\begin{array}{c}\text { overseas } \\
\text { inflow }\end{array}$ & 1 & & 9 & $1 / 26 / 2020$ & $\begin{array}{c}1 / 30 / 202 \\
0\end{array}$ & $\begin{array}{c}2 / 15 / 20 \\
20\end{array}$ & & released \\
\hline $\begin{array}{l}10000 \\
00005 \\
\end{array}$ & 9 & $\begin{array}{l}\text { fem } \\
\text { ale }\end{array}$ & 1992 & $20 \mathrm{~s}$ & $\begin{array}{c}\text { Kor } \\
\text { ea }\end{array}$ & $\begin{array}{c}\text { Seou } \\
1\end{array}$ & $\begin{array}{c}\text { Seongb } \\
\text { uk-gu }\end{array}$ & & $\begin{array}{c}\text { contact } \\
\text { with } \\
\text { patient }\end{array}$ & 2 & $\begin{array}{l}10000 \\
00002\end{array}$ & 2 & & $\begin{array}{c}1 / 31 / 202 \\
0\end{array}$ & $\begin{array}{c}2 / 24 / 20 \\
20\end{array}$ & & released \\
\hline $\begin{array}{l}10000 \\
00006\end{array}$ & 10 & $\begin{array}{c}\text { fem } \\
\text { ale }\end{array}$ & 1966 & $50 \mathrm{~s}$ & $\begin{array}{c}\text { Kor } \\
\text { ea }\end{array}$ & $\begin{array}{c}\text { Seou } \\
1\end{array}$ & $\begin{array}{l}\text { Jongno- } \\
\text { gu }\end{array}$ & & $\begin{array}{l}\text { contact } \\
\text { with } \\
\text { patient }\end{array}$ & 3 & $\begin{array}{l}10000 \\
00003\end{array}$ & 43 & & $\begin{array}{c}1 / 31 / 202 \\
0\end{array}$ & $\begin{array}{c}2 / 19 / 20 \\
20\end{array}$ & & released \\
\hline $\begin{array}{l}10000 \\
00007\end{array}$ & 11 & $\underset{\mathrm{e}}{\mathrm{mal}}$ & 1995 & $20 \mathrm{~s}$ & $\begin{array}{c}\text { Kor } \\
\text { ea }\end{array}$ & $\begin{array}{c}\text { Seou } \\
1\end{array}$ & $\begin{array}{c}\text { Jongno- } \\
\text { gu }\end{array}$ & & $\begin{array}{l}\text { contact } \\
\text { with } \\
\text { patient }\end{array}$ & 3 & $\begin{array}{l}10000 \\
00003\end{array}$ & 0 & & $\begin{array}{c}1 / 31 / 202 \\
0\end{array}$ & $\begin{array}{c}2 / 10 / 20 \\
20\end{array}$ & & released \\
\hline $\begin{array}{l}10000 \\
00008\end{array}$ & 13 & $\underset{\mathrm{e}}{\mathrm{mal}}$ & 1992 & $20 \mathrm{~s}$ & $\begin{array}{c}\text { Kor } \\
\text { ea }\end{array}$ & $\begin{array}{c}\text { Seou } \\
1\end{array}$ & etc & & $\begin{array}{l}\text { overseas } \\
\text { inflow }\end{array}$ & 1 & & 0 & & $2 / 2 / 2020$ & $\begin{array}{c}2 / 24 / 20 \\
20\end{array}$ & & released \\
\hline $\begin{array}{l}10000 \\
00009\end{array}$ & 19 & $\underset{\mathrm{e}}{\mathrm{mal}}$ & 1983 & $30 \mathrm{~s}$ & $\begin{array}{c}\text { Kor } \\
\text { ea }\end{array}$ & $\begin{array}{c}\text { Seou } \\
1\end{array}$ & $\begin{array}{l}\text { Songpa- } \\
\text { gu }\end{array}$ & & $\begin{array}{c}\text { overseas } \\
\text { inflow }\end{array}$ & 2 & & 68 & & $2 / 5 / 2020$ & $\begin{array}{c}2 / 21 / 20 \\
20\end{array}$ & & released \\
\hline $\begin{array}{l}10000 \\
00010\end{array}$ & 21 & $\begin{array}{c}\text { fem } \\
\text { ale }\end{array}$ & 1960 & $60 \mathrm{~s}$ & $\begin{array}{c}\text { Kor } \\
\text { ea }\end{array}$ & $\begin{array}{c}\text { Seou } \\
1\end{array}$ & $\begin{array}{l}\text { Seongb } \\
\text { uk-gu }\end{array}$ & & $\begin{array}{l}\text { contact } \\
\text { with } \\
\text { patient }\end{array}$ & 3 & $\begin{array}{l}10000 \\
00003\end{array}$ & 6 & & $2 / 5 / 2020$ & $\begin{array}{c}2 / 29 / 20 \\
20\end{array}$ & & released \\
\hline $\begin{array}{l}10000 \\
00011\end{array}$ & 23 & $\begin{array}{l}\text { fem } \\
\text { ale }\end{array}$ & 1962 & $50 \mathrm{~s}$ & $\begin{array}{l}\text { Chi } \\
\text { na }\end{array}$ & $\begin{array}{c}\text { Seou } \\
1\end{array}$ & $\begin{array}{l}\text { Seodae } \\
\text { mun-gu }\end{array}$ & & $\begin{array}{l}\text { overseas } \\
\text { inflow }\end{array}$ & 1 & & 23 & & $2 / 6 / 2020$ & $\begin{array}{c}2 / 29 / 20 \\
20\end{array}$ & & released \\
\hline $\begin{array}{l}10000 \\
00012\end{array}$ & 24 & $\begin{array}{c}\mathrm{mal} \\
\mathrm{e}\end{array}$ & 1992 & $20 \mathrm{~s}$ & $\begin{array}{c}\text { Kor } \\
\text { ea }\end{array}$ & $\begin{array}{c}\text { Seou } \\
1\end{array}$ & etc & & $\begin{array}{l}\text { overseas } \\
\text { inflow }\end{array}$ & 1 & & 0 & & $2 / 7 / 2020$ & $\begin{array}{c}2 / 27 / 20 \\
20\end{array}$ & & released \\
\hline
\end{tabular}


Data tersebut memiliki beberapa atribut yang tidak diperlukan dalam proses pengolahan. Maka dari itu proses selanjutnya adalah memilih atribut yang dibutuhkan. Atribut yang digunakan dalam penelitian ini adalah sex, age, city, infection case, dan state. Atribut state berfungsi sebagai label keputusan yang akan dihasilkan. Terdapat dua class pada atribut state yang digunakan yaitu released dan isolated.

Tabel 2. Contoh Data Patien info Setelah Pemilihan Atribut

\begin{tabular}{|c|c|c|c|c|}
\hline sex & age & city & infection_case & state \\
\hline male & 50 s & Gangseo-gu & overseas inflow & released \\
\hline male & 30 s & Jungnang-gu & overseas inflow & released \\
\hline male & 50 s & Jongno-gu & contact with patient & released \\
\hline male & 20 s & Mapo-gu & overseas inflow & released \\
\hline female & 20 s & Seongbuk-gu & contact with patient & released \\
\hline female & 50 s & Jongno-gu & contact with patient & released \\
\hline male & $20 \mathrm{~s}$ & Jongno-gu & contact with patient & released \\
\hline male & $20 \mathrm{~s}$ & etc & overseas inflow & released \\
\hline male & $30 \mathrm{~s}$ & Songpa-gu & overseas inflow & released \\
\hline female & $60 \mathrm{~s}$ & Seongbuk-gu & contact with patient & released \\
\hline female & $50 \mathrm{~s}$ & Seodaemun-gu & overseas inflow & released \\
\hline male & $20 \mathrm{~s}$ & etc & overseas inflow & released \\
\hline male & $80 \mathrm{~s}$ & Jongno-gu & contact with patient & released \\
\hline female & $60 \mathrm{~s}$ & Jongno-gu & contact with patient & released \\
\hline male & $70 \mathrm{~s}$ & Seongdong-gu & Seongdong-gu APT & isolated \\
\hline male & $70 \mathrm{~s}$ & Jongno-gu & contact with patient & released \\
\hline male & $70 \mathrm{~s}$ & Jongno-gu & contact with patient & released \\
\hline male & $20 \mathrm{~s}$ & etc & etc & isolated \\
\hline female & $70 \mathrm{~s}$ & Jongno-gu & contact with patient & released \\
\hline
\end{tabular}

Setelah pemilihan atribut, kemudian menghapus data kosong. Proses menghilangkan data kosong ini dilakukan dengan melakukan sorting data kosong atau blank. Data yang didapatkan sebanyak 2420 data setelah melalui proses sorting. Dan data tersebut yang diterapkan di Rapidminer untuk proses pembuatan model data mining menggunakan algoritma $\mathrm{C} 4.5$, Nä̈ve Bayes, dan k-NN.

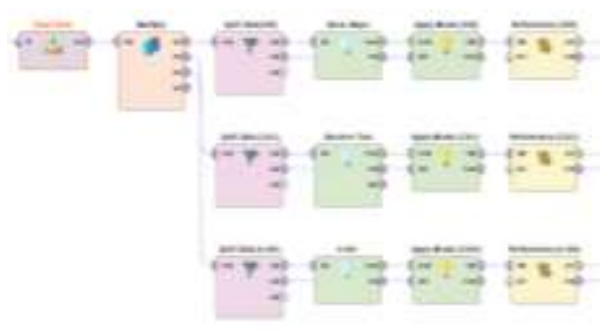

Gambar 2. Model Rapidminer Algoritma Klasifikasi

Setelah data dimasukkan ke dalam RapidMiner, jalankan model RapidMiner. Setelah RapidMiner dijalankan, maka akan tampil hasil sebagai berikut.
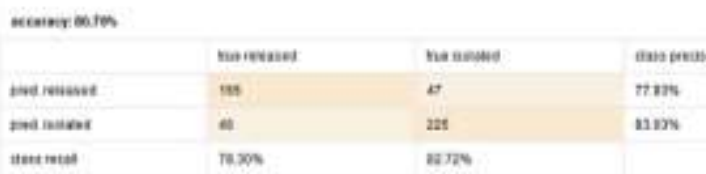

Gambar 3. Hasil Akurasi Nä̈ve Bayes

Dari proses Rapidminer menggunakan algoritma Nä̈ve Bayes menghasilkan akurasi sebesar 80,79\% yang ditunjukkan pada gambar diatas. 


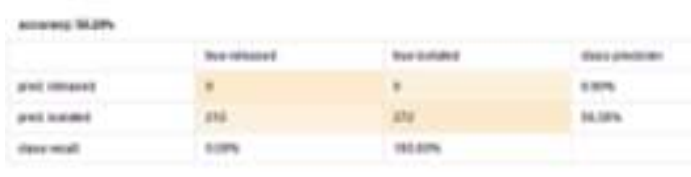

Gambar 4. Hasil Akurasi C4.5

Untuk algoritma C4.5 mendapatkan hasil akurasi yang lebih kecil dari Nä̈ve Bayes dengan hasil 54,20\%.

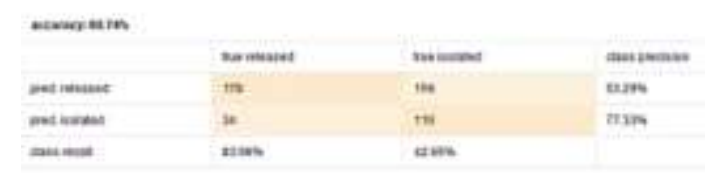

\section{Gambar 5. Hasil Akurasi k-NN}

Sedangkan hasil yang didapatkan pada algoritma k-NN mendapatkan akurasi 60,74\%. Perbandingan akurasi dari ketiga algoritma dapat dilihat pada tabel berikut.

Tabel 3. Perbandingan Akurasi Algoritma C4.5, Nä̈ve Bayes, dan k-NN

\begin{tabular}{|l|l|l|}
\hline \multicolumn{1}{|c|}{ Algoritma } & Akurasi & \multicolumn{1}{c|}{ AUC } \\
\hline Nä̈ve Bayes & $80.79 \%$ & 0.881 \\
\hline C4.5 & $56.20 \%$ & 0.743 \\
\hline k-NN & $60.74 \%$ & 0.567 \\
\hline
\end{tabular}

Dari tabel di atas dapat dilihat untuk nilai akurasi yang dicapai dari ketiga algoritma. Nä̈ve Bayes memiliki akurasi 80,79\% dengan AUC 0.881, algoritma C4.5 mendapatkan akurasi 56,20\% dengan AUC 0.743 dan k-NN mendapatkan akurasi 60,74\% dengan AUC 0.567. Jika ketiga algoritma tersebut dibandingkan maka nilai akurasi dan AUC terbaik adalah algoritma Nä̈ve Bayes. Berikut adalah penyebaran data dari algoritma Nä̈ve Bayes.

\section{Tabel 4. Penyebaran Data pada}

Algotima Nä̈ve Bayes

\begin{tabular}{|l|l|l|l|}
\hline Attribute & Parameter & released & isolated \\
\hline sex & value=female & 0.555 & 0.560 \\
\hline sex & value=male & 0.445 & 0.440 \\
\hline infection_case & $\begin{array}{l}\text { value=contact with } \\
\text { patient }\end{array}$ & 0.346 & 0.388 \\
\hline infection_case & value=overseas inflow & 0.074 & 0.305 \\
\hline age & value=20s & 0.251 & 0.233 \\
\hline infection_case & value=etc & 0.279 & 0.175 \\
\hline age & value=50s & 0.177 & 0.168 \\
\hline age & value=30s & 0.163 & 0.144 \\
\hline age & value=60s & 0.096 & 0.139 \\
\hline age & value=40s & 0.187 & 0.132 \\
\hline city & value=Seongnam-si & 0.000 & 0.086 \\
\hline age & value=70s & 0.037 & 0.069 \\
\hline age & value=10s & 0.038 & 0.048 \\
\hline city & value=Gyeongsan-si & 0.033 & 0.046 \\
\hline age & value=80s & 0.026 & 0.043 \\
\hline
\end{tabular}

\section{IV.SiMPULAN}

Hasil dari klasifikasi pada penelitian ini dengan atribut sex, age, city, infection case, dan state menggunakan algoritma C4.5, Nä̈ve Bayes, dan k-NN pada Rapidminer menghasilkan banyak pasien masuk ke class isolated. Dari ketiga algoritma, didapatkan akurasi tertinggi dari algoritma Naïve Bayes dengan hasil $80,79 \%$ dengan hasil isolated dan memiliki AUC 0.881 yang dikategorikan sebagai good clasification atau klasifikasi yang baik. Adapun hasil distribusi data yang didapatkan bahwa atribut yang berpengaruh dari faktor class isolated dari 
pasien terdapat pada atribut sex dimana female lebih banyak yang mengalami isolated dari algoritma Nä̈ve Bayes.

\section{DAFTAR PUSTAKA}

[1] C. Sohrabi et al., "World Health Organization declares global emergency: A review of the 2019 novel coronavirus (COVID-19)," International Journal of Surgery. 2020, doi:

10.1016/j.ijsu.2020.02.034.

[2] P. Sun, X. Lu, C. Xu, W. Sun, and B. Pan, "Understanding of COVID19 based on current evidence," Journal of Medical Virology. 2020, doi: 10.1002/jmv.25722.

[3] S. A. Rasmussen, J. C. Smulian, J. A. Lednicky, T. S. Wen, and D. J. Jamieson, "Coronavirus Disease 2019 (COVID-19) and Pregnancy: What obstetricians need to know.," Am. J. Obstet. Gynecol., 2020, doi: 10.1016/j.ajog.2020.02.017.

[4] H. Al-Najjar and N. Al-Rousan, “A classifier prediction model to predict the status of Coronavirus CoVID-19 patients in South Korea," Eur. Rev. Med. Pharmacol. Sci., vol. 24, no. 6, pp. 3400-3403, 2020, doi:

10.26355/eurrev_202003_20709.

[5] L. J. Muhammad, M. M. Islam, S.
S. Usman, and S. I. Ayon,

"Predictive Data mining Models for Novel Coronavirus (COVID-19) Infected Patients' Recovery," SN Comput. Sci., vol. 1, no. 4, pp. 1-7, 2020, doi: 10.1007/s42979-02000216-w.

[6] R. A. Saputra, "Komparasi Algoritma Klasifikasi Data mining Untuk Memprediksi Penyakit Tuberculosis ( $\mathrm{Tb}$ ): Studi Kasus Puskesmas Karawang," Semin. Nas. Inov. dan Tren, 2014.

[7] W. D. Septiani, "Komparasi Metode Klasifikasi Data mining Algoritma C4.5 Dan Naive Bayes Untuk Prediksi Penyakit Hepatitis," J. Pilar Nusa Mandiri, vol. 13, no. 1, pp. 76-84, 2017.

[8] F. Parung, "Penerapan algoritma decision tree c 4.5 dalam penerimaan guru pada smk sirajul falah parung," vol. 11, no. 2, pp. 192-198, 2018.

[9] I. G. Harsemadi, M. Sudarma, and N. Pramaita, "Implementasi Algoritma K-Nearest Neighbor pada Perangkat Lunak Pengelompokan Musik untuk Menentukan Suasana Hati," Maj. Ilm. Teknol. Elektro, vol. 16, no. 1, pp. 14-20, 2017, doi: 10.24843/mite.1601.03. 
[10] Sabita, H., \& Herwanto, R. (2020).

Pantauan Prediktif Covid-19 Dengan

Menggunakan Metode SIR dan

Model Statistik Di

Indonesia. TEKNIKA, 14(2), 145-

150. 